\title{
Endoparasites infecting the semiaquatic coral snake Micrurus surinamensis (Squamata: Elapidae) in the southern amazonian region, Mato Grosso state, Brazil
}

\author{
Ávila, $R W^{a}{ }^{*}$, Morais, DH. ${ }^{b}$, Anjos, LA. ${ }^{c}$, Almeida, WO. ${ }^{d}$ and Silva, RJ. ${ }^{b}$ \\ ${ }^{a}$ Departamento de Ciências Biológicas, Centro de Ciências Biológicas e da Saúde, Universidade Regional do Cariri, \\ Campus do Pimenta, Rua Cel. Antonio Luiz 1161, Bairro do Pimenta, CEP 63105-100, Crato, Ceará, Brazil \\ ${ }^{b}$ Departamento de Parasitologia, Instituto de Biociências, Universidade Estadual Paulista "Júlio de Mesquita Filho" - \\ UNESP, Campus de Botucatu, Botucatu, SP, Brazil \\ 'Departamento de Biologia e Zootecnia, Universidade Estadual Paulista “Júlio de Mesquita Filho" - UNESP, \\ Passeio Monção 226, CEP 15385-000, Ilha Solteira, SP, Brazil \\ ${ }^{d}$ Departamento de Química Biológica, Universidade Regional do Cariri, Rua Cel. Antônio Luiz 1161, \\ CEP 63105-000, Crato, CE, Brazil \\ *e-mail: robsonavila@gmail.com
}

Received April 12, 2012 - Accepted August 28, 2012 - Distributed August 31, 2013

\begin{abstract}
A parasitological survey was conducted in specimens of the semiaquatic coral snake Micrurus surinamensis, a poorly known South American elapid. Four specimens collected at the southern Amazon region in the Brazilian state of Mato Grosso were analyzed for endoparasites. Three parasite species were recovered from the snake hosts: the pentastomid Sebekia oxycephala, the nematode Physaloptera sp. and the trematode Opisthogonimus lecithonotus. This represents new locality and host record for S. oxycephala and O. lecithonotus.
\end{abstract}

Keywords: parasitism, Pentastomida, Nematoda, Trematoda, snakes.

\section{Endoparasitas infectando a coral semiaquática Micrurus surinamensis (Squamata: Elapidae) no sul da Amazônia, Mato Grosso, Brasil}

\section{Resumo}

Um estudo parasitológico foi conduzido em espécimes da cobra coral semiaquática Micrurus surinamensis, espécie de elapídeo sulamericano pouco conhecida. Quatro exemplares coletados na região sul da Amazônia, no norte do estado de Mato Grosso foram analisados quanto a presença de endoparasitas. Três espécies de parasitas foram encontradas: o pentastomídeo Sebekia oxycephala, o nematódeo Physaloptera sp. e o trematódeo Opisthogonimus lecithonotus. Isso representa novo registro de localidade e hospedeiro para S. oxycephala e O. lecithonotus.

Palavras-chave: parasitismo, Pentastomida, Nematoda, Trematoda, serpentes

\section{Introduction}

The coral snake genus Micrurus Wagler 1824 comprises 76 species restricted to the Western hemisphere, occupying almost all of the major biomes of the Neotropics (Roze, 1996; Campbell and Lamar, 2004). Many studies on natural history of this genus have been recently published (Marques, 2002; Aguiar and Di-Bernardo, 2007; Ávila et al., 2010), including those dealing with parasites associated with these snakes (Pizzato and Madi, 2002; Silva and Barrella, 2002; Almeida et al., 2007; Santos et al., 2008; MacAllister et al., 2010).

The semiaquatic coral snake Micrurus surinamensis is widely distributed in equatorial forests in six countries of South America, feeding mainly on bony fishes and eels (Roze, 1966; Morais et al., 2011). In Brazil, this snake has been reported in the states of Acre, Amazonas,
Roraima, Rondônia, Pará, Maranhão, Tocantins, Goiás and Mato Grosso (Passos and Fernandes, 2005; Silva Jr. et al., 2008; Morais et al., 2011). Despite this huge distribution, many biological aspects of M. surinamensis have been poorly studied, especially regarding parasitism. The purpose of this note is to report the occurrence of nematode, trematode and pentastomid parasites in $M$. surinamensis.

\section{Material and Methods}

Four specimens of Micrurus surinamensis previously fixed and housed in the "Coleção Zoológica de Vertebrados da Universidade Federal de Mato Grosso," Cuiabá, Brazil (UFMT) were analyzed for parasites. The snakes were collected at three municipalities from Mato Grosso State, all of them in small streams inside alluvial 
forest in the Amazonian region: one specimen from Juara municipality, a region characterized by the transition of Cerrado-Amazon areas (UFMT 5950; adult female, 968 $\mathrm{mm}$ SVL), one from Cotriguaçu municipality, also a region of Cerrado-Amazon transition (UFMT 9270, adult female, $640 \mathrm{~mm} \mathrm{SVL}$ ), and two from Colniza municipality (UFMT 7164, adult female, $782 \mathrm{~mm} \mathrm{SVL}$; UFMT 7170 , adult male, $678 \mathrm{~mm} \mathrm{SVL}$ ), a region characterized by Alluvial forest. The snakes were initially preserved in $10 \%$ formalin and then stored in $70 \%$ ethanol. A midventral incision was made in the body wall, and organ surfaces were visually checked for parasites. Subsequently, the lungs and digestive tract were examined under a stereomicroscope for parasites. For identification, nematodes were cleared in phenol, pentastomids were cleared in a drop of Hoyer's medium and trematodes were stained with carmine and cleared in creosote. All parasites were counted and deposited in the Coleção Helmintológica do Instituto de Biociências (CHIBB) at Universidade Estadual Paulista Júlio de Mesquita Filho, São Paulo State, Brazil.

\section{Results and Discussion}

We recovered 73 specimens of three parasite species (Table 1): 50 larvae of the nematode Physaloptera sp. from the stomach of one snake host (CHIBB 6743); 20 adults of the trematode Opisthogonimus lecithonotus from the mouth and esophagus of one snake host (CHIBB 5068); and 3 nymphs of the pentastomid Sebekia oxycephala in the body cavity of two snake hosts, infected with 1 or 2 nymphs (CHIBB 6744).

Currently, four species of Physaloptera have been reported infecting reptiles from South America (Physaloptera liophis, P. obtusissima, P. lutzi, and P. retusa), and identification is based on male caudal morphology and length of spicules (Vicente et al., 1993). Our specimen could not be identified due to their immature condition. Usually these nematodes use amphibians, lizards and snakes as intermediate hosts (Anderson, 2000).

The pentastomid Sebekia oxycephala is widely distributed, occurring from the southern part of the United States to southern South America (Almeida et al., 2010). In Brazil, nymphs of $S$. oxycephala have been reported parasitizing four freshwater fish species: Serrasalmus nattereri, Pseudoplatystoma corruscans and Phallocerus harpagus (see Almeida et al., 2010) and Serrasalmus marginatus (Vicentin et al., 2011). Adults of this pentastomid have been reported infecting crocodilian species (Junker and Boomker, 2006). The life cycle of S. oxycephala is well known and involves several freshwater fish species as intermediate hosts (Venard and Bangham, 1941; Riley, 1986; Almeida et al., 2010). Heymons (1935) suggested that nymphs of this pentastomid may also infect lizards and snakes, but Riley (1986) considered the source of this information vague and pointed out the need for confirmation. However, nymphs of Sebekia have been reported to infect other Neotropical snakes, such as Helicops leopardinus (Rego and Vicente, 1988), Nerodia spp. (Overstreet et al., 1985), and Micrurus surinamensis (this work). The infection of these snakes with nymphs of Sebekia, could be related to their semiaquatic habitats (Ávila et al., 2006; Morais et al., 2011; Mushinsky et al., 1982), since nymphs of Sebekia actively infect their intermediate hosts (Junker et al., 1998). Moreover, the reports of Sebekia infecting the terrestrial coral snake Micrurus alleni (Goldberg and Bursey, 2004) could be explained by their piscivorous diet (Roze, 1996; Cunha and Nascimento, 1978).

Opistogonimus lecithonotus were reported from the oral cavity and esophagus of 22 Neotropical snake species, including one coral snake, Micrurus pyrrhocryptus (Lunaschi and Drago, 2007). Snakes infected by $O$. lecithonotus show a high phylogenetic distance and belong to several genera and families (e.g., Dipsadidae, Colubridade, Viperidae and Elapidae; see Lunaschi and Drago, 2007), with a wide variety of habits (e.g., terrestrial, aquatic, semifossorial) and prey types (e.g., anurans, fishes, snakes, mammals, etc), thus making it difficult to provide general predictions about which ecological aspects of the hosts make them susceptible to infection by this trematode.

In conclusion, despite of our small sample size, the present study makes an important contribution to our knowledge of parasitism in snakes of South America, since $M$. surinamensis represents a new host record for these three parasite species. Moreover, the state of Mato Grosso is a new locality record for $S$. oxycephala and $O$. lecithonotus. Hence, we strongly suggest more studies dealing with parasitism in Neotropical snakes, especially regarding elapids, for a better understanding of ecological processes, such as infracommunity structure and infection patterns.

Table 1 - Epidemiological data for four Micrurus surinamensis and their nematode parasites at the southern Amazonian region, Mato Grosso State, Brazil. For each nematode the prevalence, intensity of infection (mean \pm one standard deviation), mean abundance and the sites of infection are given. Abbreviations are: $\mathrm{BC}=$ Body cavity and $\mathrm{MO}=$ Mouth.

\begin{tabular}{lcccccc}
\hline Parasite species & N & $\begin{array}{c}\text { Prevalence } \\
\mathbf{( \% )}\end{array}$ & $\begin{array}{c}\text { Intensity of } \\
\text { infection }\end{array}$ & $\begin{array}{c}\text { Mean } \\
\text { abundance }\end{array}$ & $\begin{array}{c}\text { Site of infec- } \\
\text { tion }\end{array}$ & $\begin{array}{c}\text { Host voucher } \\
\text { number }\end{array}$ \\
\hline Sebekia oxycephala & 3 & 50 & 1.5 & 0.75 & BC & UFMT 7164, 7170 \\
Physaloptera sp. & 50 & 25 & 50 & 12.5 & BC & UFMT 5950 \\
Opisthogonimus lecithonotus & 20 & 25 & 20 & 5 & MO & UFMT 9270 \\
\hline
\end{tabular}




\section{Acknowledgments}

To Marcos André de Carvalho for allowing access to material under his care at the "Coleção Zoológica de Vertebrados da Universidade Federal de Mato Grosso" (UFMT). We are grateful to the to Conselho Nacional de Desenvolvimento Científico e Tecnológico - CNPq for the research grant awarded to W.O. Almeida (PQ-311713/2012-2); to Fundação Cearense de Apoio ao Desenvolvimento Científico e Tecnológico - FUNCAP for the research grant awarded to R.W. Ávila (BPI-0067-00006.01.00/12).

\section{References}

AGUIAR, LFS. and DI-BERNARDO, M., 2007. Micrurus altirostris. Herpetological Review, vol. 38, no. 2, p. 209.

ALMEIDA, WO., SILVA-SOUZA, AT. and SALES, DL. 2010. Parasitism of Phalloceros harpagos (Cyprinodontiformes: Poeciliidae) by Sebekia oxycephala (Pentastomida: Sebekidae) in the headwaters of the Cambé River, Paraná State, Brazil. Brazilian Journal of Biology, vol. 70, no. 2 , p. $457-458$.

ALMEIDA, WO., VASCONCELLOS, A., LOPES, SG., and FREIRE, EMX., 2007. Prevalence and intensity of pentastomid infection in two species of snakes from Northeastern Brazil. Brazilian Journal of Biology, vol. 67, no. 4, p. 759-763.

ÁVILA, RW., FERREIRA, VL. and ARRUDA, JAO., 2006. Natural history of the South American water snake Helicops leopardinus (Serpentes: Colubridae) in the Pantanal, Brazil. Journal of Herpetology, vol. 40, no. 2, p. 274-279.

ÁVILA, RW., KAWASHITA-RIBEIRO, RA., FERREIRA, VL., and STRÜSSMANN, C., 2010. Natural history of the coral snake Micrurus pyrrhocryptus Cope 1862 (Elapidae) from semideciduous forests of western Brazil. South American Journal of Herpetology, vol. 5, no. 2, p. 97-101.

BUSH, AO., LAFFERTY, KD., LOTZ, JM. and SHOSTAK, AW., 1997. Parasitology meets ecology on its own terms: Margolis et al. revisited. Journal of Parasitology, vol. 83, p. $575-583$.

CAMPBELL, JA. and LAMAR, WW., 2004. The Venomous Reptiles of the Western Hemisphere. New York: Comstock, Ithaca \& London. $810 \mathrm{p}$

CUNHA, OR. and NASCIMENTO, FP., 1978. Ofídios da Amazônia. X - As cobras da região leste do Pará. Publicações Avulsas do Museu Paraense Emílio Goeldi, vol. 31, p. 1-218.

GOLDBERG, SR. and BURSEY, CR., 2004. Coelomic Metazoan Endoparasites of 15 Colubrid and Two Elapid Snake Species from Costa Rica. Caribbean Journal of Science, vol. 40, no. 1, p. 62-69.

HEYMONS, R., 1935. Bronn's Klassen und Ordnungen des Tierreichs: Pentastomida. Leipzig: Akademische Verlagsgesellschaft MBH. vol. 5, seção 4, livro 1.

JUNKER, K. and BOOMKER, J., 2006. A check-list of the pentastomid parasites of crocodilians and freshwater chelonians. Onderstepoort Journal of Veterinary Research, vol. 73, p. 27-36.

JUNKER, K., BOOMKER, J. and BOOYSE, DG., 1998. Experimental studies on the life-cycle of Sebekia wedli (Pentastomida: Sebekidae). Onderstepoort Journal of Veterinary Research, vol. 65, p.233-237.
LUNASCHI, LI. and DRAGO, FB., 2007. Checklist of digenean parasites of amphibians and reptiles from Argentina. Zootaxa, vol. 1476, p. 51-68.

MARQUES, OAV., 2002. Natural history of the coral snake Micrurus decoratus (Elapidae) from the Atlantic forest in southeast Brazil, with comments on possible mimicry. Amphibia-Reptilia, vol. 23, p. 228-232.

MCALLISTER CT., BURSEY CR. and FREED PS., 2010 Helminth parasites (Cestoda: Nematoda) of selected herpetofauna from Paraguay. Journal of Parasitology, vol. 96 , no. 1, p. 222-4.

MORAIS, DH., ÁVILA, RW., KAWASHITA-RIBEIRO, RA. and CARVALHO, MA., 2011. Squamata, Elapidae, Micrurus surinamensis (Cuvier, 1817): New records and distribution map in the state of Mato Grosso, Brazil, with notes on diet and activity period. Checklist, vol. 7, p. $350-351$.

MUSHINSKY, HR., HEBRARD, JJ. and VODOPICH, S., 1982. Ontogeny of water snake foraging ecology. Ecology, vol. 63, p.1624-1629.

OVERSTREET, RM., SELF, JT. and VLIET, KA., 1985. The pentastomid Sebekia mississippiensis sp. $\mathrm{n}$. in the American alligator and other hosts. Proceedings of the Helminthological Society of Washington, vol. 52, p. 266-277.

PASSOS, P. and FERNANDES, DS., 2005. Variation and taxonomic status of the coral snake Micrurus surinamensis (Cuvier, 1817) (Serpentes: Elapidae). Zootaxa, vol. 953, p. 1-14.

PIZZATTO, L. and MADI, RR., 2002. Micrurus coralinus (coral snake). Endoparasites. Herpetological Review, vol. 33 , no. 3, p. 215.

REGO, AA. and VICENTE, JJ., 1988. Excursão científica à Zona do Pantanal, Estado de Mato Grosso, para coletas de helmintos. Ciência e Cultura, vol. 40, p. 65-68.

RILEY, J., 1986. The biology of pentastomids. Advances in Parasitology, vol. 25, p. 45-128.

ROZE, JA., 1996. Coral Snakes of the Americas: Biology, Identification, and Venoms. Malabar, Florida, USA: Krieger Publishing Company. 328 p.

SANTOS, KR., BARRELLA, TH., ZICA, EOP. and SILVA, RJ., 2008. New reports on parasitism by Haplometroides buccicola (Digenea, Plagiorchiidae) in Brazilian snake. Journal of Venomous Animals and Toxins Including Tropical Diseases (Online), vol. 14, no. 3, p. 527-532.

SILVA RJ. and BARRELLA TH., 2002. Micrurus frontalis as a new host recorded for Haplometroides odhneri (Trematoda, Digenea, Plagiorchiidae). Revista Brasileira de Parasitologia Veterinária, vol. 11, p. 47-8.

SILVA JR, NJ., SILVA, HLR. and PESSOA, AM., 2008. Micrurus surinamensis (Surinam Coralsnake). Geographic Distribution. Herpetological Review, vol. 39, p. 372.

VENARD, CE., and BANGHAM, RV., 1941. Sebekia oxycephala (Pentastomida) from Florida Fishes and Some Notes on the Morphology of the Larvae. Ohio Journal of Science, vol. 41, p. 23-28.

VICENTE, JJ., RODRIGUES, HO., GOMES, DC. and PINTO, RM., 1993. Nematóides do Brasil. Parte III: Nematóides de répteis. Revista Brasileira de Zoologia, vol. 10, no. 1, p. 19-168.

VICENTIN, W., VIEIRA, KRI., COSTA, FES., TAKEMOTO, RM., TAVARES, LER. and PAIVA, F., 2011. Metazoan endoparasites of Serrasalmus marginatus (Characiformes: Serrasalminae) in the Negro River, Pantanal, Brazil. Revista Brasileira de Parasitologia Veterinária, vol. 20, no. 1, p. 61-63. 